\title{
Implikasi Trip's Terhadap Konvensi Keanekaragaman Hayati
}

\author{
Sri Wartini
}

\section{Abstrak}

The Protection of Intellectual Property Rights regulated on TRIP's raises negative and positive impacts to the Biological Diversity Convention. The Protection of Intellectual Property Rights applied to invention on the biotechnology encourages people to invent a new variety of plant, on the other hand, the Protection of Intellectual Property Rights causes disadvantages to the developing countries such as patented of traditional knowledge owned by Indigenous people of a State or patented of a certain kind of plant. Furthermore. TRIP's also raises negative impact to the objective of the Biological Diversity Convention, such as the decrease of biological diversity.

\section{Pendahuluan}

Liberalisasi perdagangan di bidang pertanian yang tertuang dalam persetujuan pertanian ( Agreement on Agriculture) dalam Putaran Uruguay telah mengubah pola produksi pertanian yang beraneka ragam dan berskala kecil menjadi pola produksi pertanian besar yang bersifat monokultur. ${ }^{1}$ Hal tersebut menyebabkan ketidakseimbangan ekosistem dan bahkan akan dapat merusak lingkungan. Ketentuan perlindungan Hak atas Kekayaan Intelektual dalam Agreement on Trade-Related Aspects of Intellectual Property Rights - World Trade Oganization (TRIP's - WTO), menimbulkan pertentangan dengan pelestarian keanekaragaman hayati.

Agreement on Trade Related Aspects of Intellectual Property Rights (TRIP's) mengatur tentang akses dan pemanfaatan penemuan yang merupakan kreativitas manusia. Secara tradisional, hukum yang dimaksudkan untuk melindungi penemuan tersebut biasanya untuk penggunaan dalam bidang industri dan design. Akan tetapi dengan semakin berkembangnya teknologi, maka orang pun telah mampu untuk membuat suatu produk yang berasal dari micro-organisme ataupun penciptaan varietas tanaman baru dengan menggunakan teknik rekayasa genetika. Dengan demikian hasil temuan dan inovasi baru ini juga tercakup dalam regim hokum perlindungan hak atas kekayaan intelektual.

Dimasukkannya materi biologi kedalam sistem perlindungan hak atas kekayaan intelektual, adalah atas desakan kuat dari

'WTO Secretariat (ed), Trade, Development and the Environment, Kluwer Law International, London, 2000, hlm. 72. 
negara-negara maju. Menurut negara-negara maju kurangnya perlindungan terhadap sumber-sumber biologi akan menyebabkan hambatan dalam perdagangan bebas yang dilarang dalam WTO. Akses terhadap sumber-sumber genetic yang berada di wilayah selatan menyebabkan negara-negara maju dapat memanfaatkan sumber-sumber tersebut untuk tujuan komersial, seperti obatobatan dan penciptaan varietas tanaman baru.

Dengan dipatenkannya penemuanpenemuan tersebut, akan mengakibatkan negara-negara maju memperoleh kembali modalnya yang telah mereka gunakan dalam penelitian untuk penemuan produk-produk tersebut. Argumentasi yang digunakan untuk mengadopsi TRIP's didasarkan pada suatu asumsi bahwa dengan adanya perlindungan hak atas kekayaan intelektual yang kuat akan merupakan suatu insentif bagi inovasi dan penemuan-penemuan baru, dan menciptakan suatu tehnologi baru di negara-negara maju. Melalui penanaman modal asing dan alih teknologi akan mendorong negara-negara berkembang untuk berpartisipasi dalam pasar internasional dan memfasilitasi pembangunan negara berkembang.

Mekanisme pembagian keuntungan (benefit-sharing) yang merupakan isu pokok dalam Konvensi Keanekaragaman Hayati tidak dikenal di dalam TRIP's. Pembagian keuntungan memiliki suatu pengertian bahwa sumber daya genetic yang ada di selatan yang dimanfaatkan oleh negara-negara maju, telah menimbulkan banyak keuntungan, sehingga keuntungan tersebut seharusnya dibagi antara negara berkembang dan negara maju. Akan tetapi dengan berlakunya ketentuan TRIP's justru sebaliknya, negara-negara selatan yang memiliki sumber genetik, justru harus membayar royalty unntuk memproduksi suatu produk yang telah dipatenkan yang berasal dari sumber, genetic yang mereka miliki telah dijadikan sebagai bahan dasar suatu produk ataupun untuk penciptaan varietas tanaman. Sehingga dengan adanya regim hukum yang dimuat dalam TRIP's ini menimbulkan suatu kerugian bagi negara-negara selatan.

Dalam persetujuan TRIP's tidak dikenal atau diatur mengenai prinsip pembagian keuntungan atau ketentuan pembagian keuntungañ antara si pemegang paten dan negara yang telah memberikan genetic resourcesnya sebagai bahan mentah penciptaan suatu produk. Hal ini membuktikan adanya suatu konflik kepentingan antara TRIP's dan Konvensi Keanekaragaman Hayati. Selain itu juga ada pertentangan yang muncul antara TRIP's dan Konvensi Keanekaragaman Hayati yaitu ketentuan tentang hak berdaulat atas sumber-sumber genetic ( souvereignity over genetic resources). Dalam tulisan ini penulis tertarik untuk menganalisa bagaiman implikasi TRIP's terhadap Konvensi Keanekaragaman Hayati, khususnya ketentuan perindungan HakAtas Kekayaan Intelektual dalam invention yang menggunakan bioteknologi yang diatur dalam Konvensi Keanekaragaman Hayati.

\section{Tinjauan Umum Konvensi Keanekaragaman Hayati}

Keanekaragaman hayati memiliki fungsi yang sangat penting bagi kehidupan manusia dan lingkungannya. Keanekaragaman hayati menurut Konvensi Keanekaragaman Hayati ialah :

"the variability among living organisms from all sources, including terrestrial, marine and other aquatic ecosystems and the ecological 
complexes of which they are part; this include diversity within species, between species and ecosystems".

Berdasarkan definisi tersebut dapat ditarik suatu pengertian bahwa yang dimaksud keanekaragaman hayati adalah keanekaragaman diantara mahkluk hidup dari semua sumber, termasuk diantaranya daratan, lautan, dan ekosistem akuatik lain serta (komplekskompleks) ekologi yang merupakan bagian dari ekosistem. Keanekaragaman hayati mencakup tiga hal yaitu keragaman ekosistem, jenis (spesies) dan genetik (varietas / ras). ${ }^{3}$

Keanekaragaman ekosistem merupakan dimensi yang terpenting, sebab semua makhluk hidup berada dan melakukan fungsinya di dalam ekosistem. Oleh karena itu, perlindungan keanekaragaman hayati akan lebih efektif jika dilakukan dengan memberikan perlindungan terhadap ekosistemnya. ${ }^{4}$ Di sisi lain keanekaragaman spesies diklaim sebagai konsep yang paling sentral, karena secara tradisional spesies diposisikan sebagai tolak ukur taksonomi awal dalam mengklasifikasikan organisme hidup. Keanekaragaman genetik dianggap sebagai konsep yang paling fundamental mengingat genus yang ada di dalam dan diantara spesies tersebut merupakan bahan dasar dari inovasi dan pengembangan ilmu pengetahuan, industri dan pertanian serta diperlukan dalam mempertahankan biosfer pada saat terjadinya degradasi lingkungan yang terus berlanjut sampai saat ini. ${ }^{5}$ Walaupun demikian, ketiga hal tersebut masing-masing memiliki fungsi yang sangat penting. Oleh karena itu ketiganya harus dipandang sebagai unsur yang saling mendukung dan saling tergantung satu sama lain.

Konvensi ini bertujuan untuk melakukan konservasi keanekaragaman hayati, pemanfaatan komponen-komponennya secara berkelanjutan dan membagi keuntungan yang dihasilkan dari pendayagunaan sumber daya genetik secara adil dan merata ${ }_{1}{ }^{6}$ termasuk melalui akses yang memadai terhadap sumberdaya genetik dan dengan alih teknologi yang tepat guna, dan dengan memperhatikan semua hak atas sumber daya dan teknologi itu, maupun dengan pendanaan yang memadai.

Semakin menurunnya keanekaragaman hayati merupakan suatu masalah yang tidak saja bersifat nasional tetapi juga bersifat global,

\footnotetext{
${ }^{2}$ Pasal 1 Konvensi Keanekaragaman Hayati Tahun 1992.
}

${ }^{3}$ Kantor Menteri Negara Lingkungan Hidup dan United Nations Development Programme, Agenda 21 Indonesia : Strategi Nasional Untuk Pembangunan Berkelanjutan, Kantor Menteri Negara Lingkungan Hidup, (Jakarta, 1997), hlm.539.

${ }^{4}$ Otto Soemarwoto, Ekologi Lingkungan Hidup dan Pembangunan, (Djambatan, 1991), hlm. 20. Beliau menyatakan : "Ekosistem ialah suatu sistem ekologi yang terbentuk oleh hubungan timbal balik antara makhluk hidup dengan lingkungannya. Ekosistem terbentuk dari komponen hidup dan tak hidup di suatu tempat yang berinteraksi membentuk suatu kesatuan yang teratur. Keteraturan itu terjadi oleh adanya arus materi dan energi yang terkendalikan oleh arus informasi antara komponen dalam ekosistem itu. Masing-masing komponen itu mempunyai fungsi atau relung. Selama masing-masing komponen itu melakukan fungsinya dan bekerja sama dengan baik, keteraturan ekosistem itu pun terjaga ".

${ }^{5}$ Nandang Sutrisno, "Hak Atas Kekayaan Intelektual dan Perdagangan Internasional: Implikasinya Terhadap Perlindungan Keanekaragaman Hayati ", dalam, Erman Rajagukguk (ed), 75 Tahun Prof. Dr. Koesnadi Hardjasoemantri, SH.,ML, (Program Pascasarjana Universitas Indonesia, Jakarta, 2001), hlm. 89.

${ }^{6}$ Pasal 3 Konvensi Keanekaragaman Hayati Tahun 1992. 
karena keanekaragaman hayati tidak hanya dibutuhkan oleh suatu negara saja tetapi juga dibutuhkan oleh masyarakat internasional. Oleh karena itu, dengan dilaksanakannya alih teknologi bioteknologi dari negara maju ke negara berkembang yang berwawasan lingkungan diharapkan akan mendukung salah satu tujuan Konvensi yaitu untuk memanfaatkan sumber daya hayati secara berkelanjutan.

Konvensi Keanekaragaman Hayati merupakan suatu instrumen hukum yang secara komprehensif mengatur perlindungan keanekaragaman hayati dan pemanfaatannya secara berkelanjutan. Secara garis" besar isi Konvensi Keanekaragaman Hayati dapat diklasifikasikan ke dalam empat bagian, yaitu : tujuan Konvensi; kerjasama; hak-hak negara peserta; dan kewajiban-kewajiban negara peserta.

Tujuan Konvensi sebagaimana yang tertuang dalam Pasal 1 adalah sebagai berikut:

"The objectives of this Convention, to be pursued in accordance with its relevant provisions, are conservation of biological diversity, the sustainable use of its components and the fair and equitable sharing of the benefits arising out of the utilization of genetic resources, including by appropriate access to genetic resources and by appropriate transfer of technologies taking into account all rights over those resources and to technologies, and by appropriate funding ".

Dari ketentuan pasal 1 tersebut ada tiga tujuan yang ingin dicapai oleh Konvensi ini yaitu: pertama, konservasi keanekaragaman hayati, kedua, pemanfaatan secara ber- kelanjutan komponen-komponen sumber daya genetik dan pembagian keuntungan yang adil sebagai akibat pendayagunaan sumber genetik, dan ketiga terciptanya pembagian yang adil terhadap keuntungan yang timbul dari pemanfaatan sumber daya genetik, termasuk akses terhadap sumber daya genetik dan alih teknologi yang relevan serta akses terhadap sumber dana yang memadai.

Walaupun Konvensi Keanekaragaman Hayati merupakan instrumen hukum internasional yang komprehensif, namun tidak luput dari berbagai kelemahan, baik yang bersifat teknis maupun yuridis. Diantara kelemahan-kelemahan yuridis adalah bahwa ketentuan-ketentuan yang dimuat dalam konvensi ini hanya bersifat rekomendasi atapun himbauan kepada negara peserta untuk melaksanakan kewajiban.

Kelemahan tersebut dapat menghambat pelaksanaan untuk mencapai tujuan Konvensi, karena hampir keseluruhan keanekaragaman hayati berada dalam yurisdiksi nasional. Dalam kondisi seperti ini kewajban untuk melaksanakan konservasi dan pemanfaatan berkelanjutan keanekaragaman hayati lebih dititikberatkan pada kemauan masing-masing negara untuk melaksanakan kewajiban-kewajiban yang termuat dalam konvensi secara sukarela. Dengan demikian efektifitas pelaksanaan Konvensi akan sangat tergantung pada kemauan politik masing-masing negara dan itikad baik negara-negara peserta.

Alih teknologi tanaman transgenik ${ }^{7}$ merupakan jenis teknologi baru terutama bagi negara-negara berkembang seperti Indonesia.

${ }^{7}$ A.M. Mannion dan S.R. Bowlby (ed), Environmental Issues in the 1990s, (John Wiley \& Sons L.td, 1992) hlm. 154. Menyatakan: "Tanaman transgenik dihasilkan dari rekayasa genetika melibatkan manipulasi DNA dan transfer komponen-komponen gen antar species untukmendorong replikasi desired traits. Hal tersebut dikenal dengan teknologi rekombinan DNA, cloning gen,dan manipulasi genetic secara in-vitro". 
Dalam Konvensi ini menyatakan bahwa pelaksanaan alih teknologi haruslah berwawasan lingkungan, ${ }^{8}$ artinya teknologi yang dialihkan tidak boleh menyebabkan kerusakan terhadap keanekaragaman hayati tetapi dapat memberikan nilai tambah terhadap pemanfaatan keanekaragaman hayati secara berkelanjutan. Oleh karenaitu, alih teknologi ini harus didahuluidengan pengkajian dampak lingkungan, ${ }^{9}$ dan dilaksanakan sesuai dengan prinsip-prinsip yang termuat dalam Konvensi Keanekaragaman Hayati maupun Protokol Cartagena seperti prinsip kehatihatian ( precautionary principle ) serta pembagian keuntungan yang adil (equitable benefit sharing).

Salah satu teknik yang digunakan dalam bioteknologi modem ${ }^{10}$ adalah teknik rekayasa gen atau DNA rekombinan. Teknik ini memungkinkan para ilmuwan merekayasa organisme baru (Genetically Modified Organisms) selanjutnya akan disebut GMO. GMO pada hakekatnya merupakan suatu sel hidup dengan sifat dan karakteristik yang baru sebagai akibat dari rekayasa gen-gen di dalam kromosomnya. Dengan teknik ini dihasilkan organisme baru yang disebut organisme transgenik dimana kedalam kromosom organisme tersebut digabungkan beberapa fragmen gen dari organisme yang lain. Pembuatan organisme transgenik ini tidak hanya dilakukan pada selsel prokariot" seperti virus dan bakteri, namun dapat pula dilakukan pada sel-sel eukariot ${ }^{12}$ seperti sel tanaman dan sel hewan, bahkan dari sel-sel berasal dari organ manusia.

\footnotetext{
${ }^{8}$ Preparatory Committee for UNCED "Report on the Transfer of Technology: Reportby the Secretary General of the Conference ", AConf/51/AC/53, United Nations, New York, hlm.3, menyatakan : "...less polluting, less energy and resource insentive, use renewable resource in a more suitable manner, recycle more of their wastes and products, and handle residual waste in a more acceptable manner then the technologies they replace."

${ }^{9}$ Pasal 14 Konvensi Keanekaragaman Hayati Tahun 1992.

${ }^{10}$ Sugiono Moeljoprawiro, Prospek Bioteknologi Dalam Pembangunan Pertanian, Kantor Menteri Negara lingkungan Hidup, Jakarta, 1994, hlm.37. "Beliau menyatakan bahwa bioteknologi modern seringkali masih menggunakan prinsip yang sama dengan bioteknologi konvensional. Perbedaan antara bioteknologi konvensional dengan bioteknologi modern adalah seberapa jauh suatu proses dapat dipengaruhi dan diarahkan. Bioteknologi pertanian moderen didasarkan pada dua teknik yang telah diperbaiki dan dikembangkan lebih lanjut yaitu teknik kultur jaringan dan DNA rekombinan (r-DNA)".

"M.Abercrombie, M. Hickman (et,al), Dictionary of Biology, Penguin, England, 1980, hlm. 522. "Prokariot mempunyai ciri bersel tunggal atau mempunyai filalemen dan berukuran kecil (diameter sampai $3 \mathrm{~mm}$ ). DNA tidak terbungkus dalam pembungkus nucleus dan sel prokariota tidak berasal dari sel bernukleus seperti ini. Didalam membran plasma terdapat sisa sitoplasma, seringkali berbelit dan terlipat, yang mengandung ribosom yang lebih kecil dari ribosom eukariota, bersama inklusi granula. Tidak mempunyai tubulin, aktin, dan histon yang merupakan cirri khas eukariota dan dengan demikian mempunyai cara pembelahan yang berbeda. Sandi genetiknya sangat mirip dengan eukariota. Pembelahan sel biasanya lebih lambat dari pada replikasi kromosom, sehingga sel prokariota biasanya mengandung paling sedikit dua kromosom yang masing-masing terdiriatas DNA dan protein non-histon yang seringkali untuk sementara waktu tertaut pada membran plasma. Tidak terdapat mitokondria dan kloroplas, tetapi mempunyai stuktur yang mempunyai fungsi sama".

${ }^{12} \mathrm{ld}$, hlm. 219. "Eukariot adalah organisme yang mempunyai bahan genetik kromosom sel atau selselnya disimpan di dalam satu atau lebih nucleus dan dengan demikian terpisah dari sitoplasma oleh dua membran nucleus. Beberapa sel eukorata kehilangan nukleusnya selama perkembangan; tetapi semua dibedakan dari sel-sel prokariota oleh sel-sel yang umumnya jauh lebih besar, oleh adanya protein-protein aktin, miosin,
} 
Dalam bidang pertanian, banyak sekali produk bioteknologi seperti tanaman baru, jenis hewan baru dan mikroba baru yang akan dilepas ke lingkungan. Pengkajian terhadap dampak negatif produk-produk tersebut terhadap lingkungan hanya dapat dilakukan bila telah dipelajari dengan seksama perilaku dan karakteristik dari mahluk hidup yang secara genetik telah direkayasa. Hasil pengkajian ini akan merupakan pedoman bagi para ahli dan para pengambil keputusan untuk memahami secara tepat cara-cara pengelolaan produk bioteknologi sekaligus memberi penyuluhan kepada masyarakat agar mereka memahami keuntungan dan kerugian penggunaan bioteknologi dalam kehidupan sehari-hari.

Masalah lain yang perlu diperhatikan dalam pengembangan tanaman hasil rekayasa genetika adalah masalah alih teknologi dan Hak Atas Kekayaan Intelektual (HAKI). ${ }^{3}$ Hal ini disebabkan perluasan claim yang dilakukan oleh inventor terhadap sumber- sumber genetika yang tadinya merupakan public domain setelah mengalami proses rekayasa genetika menjadi milik individu. ${ }^{14} \mathrm{Alih}$ teknologi tanaman transgenik sebagai hasil pengembangan bioteknologi tentunya harus melalui suatu seleksi yang cukup ketat, karena berkaitan dengan organisme hidup yang dimodifikasi ( Living Modified Organism) selanjutnya akan disebut LMO . Dampak yang ditimbulkan oleh tanaman hasil rekayasa genetika terhadap lingkungan maupun manusia belum dapat dipastikan secara ilmiah. ${ }^{15}$ Oleh karena itu prinsip kehati-hatian dalam alih teknologi tanaman hasil rekayasa genetika ${ }^{16}$ sangatlah diperlukan.

Konvensi Keanekaragaman Hayati mengakui bahwa negara memiliki hak berdaulat ( sovereign right) atas sumbersumber alamnya ${ }^{17}$ dan berhak untuk memperoleh keuntungan atas penggunaan sumber genetik yang dimilikinya secara komersial maupun untuk penggunaan lain. ${ }^{18}$ Oleh karena itu setiap negara berhak untuk

tubulin dan histon, oleh ribosom yang lebih pekat, dan oleh keragaman yang lebih besar dari organelorganel yang terikat membran. Pembelahan sel dengan mitosis atau miosis. Ketika terjadi pembelahan sel beberapa protein-protein tersebut akan terlibat". ${ }^{13}$ H.S. Kartadjoemena, GATT WTO dan Hasil Uruguay Round, (Ul-Press, Jakarta, 1997), hlm. 267.

${ }^{14}$ Gerad Middendort, Mike Skladany (et.al), "New Agricultural Biotechnologies : The Struggle for Democratic Choice “, (Monthly Review, New York, July-August 1998), him. 86-87.

${ }^{15}$ Phillippe Sands, Principles of International Environmental Law I Frameworks Standards and Implementation, (Manchester University Press, Manchester, 1995), hlm. 208-213.

${ }^{16}$ David P. Fidler, International Law and Public Health : Materials on and Analysis of Global Health Jurisprudence , (Transnational Publishers, Inc, New York, 2000), hlm. 467. Pasal 19 ayat 3 Konvensi Keanekaragaman Hayati : "The parties shall consider the need for and modalities of a protocol setting out appropriate procedures, including, in particular, advance informed agreement, in the field of the safe transfer, handling and use of any living modified organism resulting from biotechnology that may have adverse effect on the conservation and sustainable use of biological diversity".

${ }_{17}^{17}$ Pasal 15 Konvensi Keanekaragaman. Hayati Tahun 1992.

${ }^{18}$ Gerald Dworkin, " Trade Related Aspects of Intellectual Property Rights and GATT. " dalam Lye Lin Heng, Current Legal Issues in the Internationalization of Bussiness Enterprises, (Butterworths, Singapore, 1996), hlm. 323. ${ }^{20}$ Ahmad Azhar Basyir. Op. Cit. Hlm. 21 
mengaturnya dalam lingkup nasional untuk kepentingan dan kesejahteraan negara tersebut. indonesia belum dapat memanfaatkan secara optimum keanekaragaman hayati yang dimilikinya, karena kurangnya modal dan kemampuan teknologi rekayasa genetika tanaman. Selain itu juga belum adanya peraturanperaturan yang memadai untuk pengembangan bioteknologi modern.

Kelemahan hukum internasional dalam memberikan perlindungan lingkungan, khususnya keanekaragaman hayati terhadap aktivitas alih teknologi tanaman transgenik semakin menegaskan pentingnya penyelenggaraan pengawasan proses alih teknologi oleh negara penerima teknologi melalui berbagai macam peraturan. Namun di sisi lain peraturan-peraturan itu seringkali dianggap oleh negara maju sebagai tindakan yang bersifat anti kompetitif yang dapat menghambat arus alih teknologi itu sendiri. Hal ini perlu mendapatkan perhatian pemerintah Indonesia dalam menentukan kebijaksanaan alih teknologi. Di satu sisi masih diperlukan peraturan alih teknologi untuk melindungi kepentingan nasional, khususnya kepentingan perlindungan keanekaragaman hayati dan lingkungan. Namun di sisi lain peraturan tersebut harus dibentuk sedemikian rupa sehingga tidak menghambat arus alih teknologi.

\section{Implikasi TRIP's Terhadap Konvensi Keanekaragaman Hayati}

Hak Kekayaan Intelektual (Intellectual Property Rights ) merupakan hak hukum privat yang diterapkan terhadap kontribusi manusia yang bersifat intangible terhadap suatu teknologi tertentu. Dalam bentuknya yang sangat mendasar, hak kekayaan intelektual memberikan hak kepada pemegangnya untuk mengontrol pihak lain dalam menggunakan hak tersebut secara komersial mengenai informasi yang terkandung dalam suatu teknologi tertentu selama berlakunya hak atas kekayaan intelektual tersebut. ${ }^{19}$

Konferensi para Pihak Konvensi Keanekaragaman Hayati, menghubungkan antara isu Kekayaan Intelektual dengan alih teknologi dalam suatu pokok bahasan mengenai akses terhadap sumber genetik (Access to Genetic Resources). Pasal 15 Konvensi Keanekaragaman Hayati memberikan suatu kerangka kerja yang luas mengenai akses terhadap sumber-sumber genetik. ${ }^{20}$ Konvensi ini mengakui bahwa peraturan akses terhadap sumber genetik merupakan kewenangan nasional suatu negara. Dalam ketentuan ini juga menyangkut adanya pembagian keuntungan yang didasarkan pada kesepakatan bersama. Pembagian keuntungan ini bervariasi dapat meliputi kompensasi keuangan, training maupun keterlibatan dalam penelitian maupun alih teknologi.

${ }^{19}$ Jeffrey A. McNeely and Lothar Gundling, "Guide to the Convention on Biological Diversity ", Environmental Policy and Law Paper No. 30, (IUCN - The World Conservation Union, 1994), hlm. 87.

${ }^{20}$ Gerald Dworkin, "Trade Related Aspects of Intellectual Property Rights and GATT." dalam Lye Lin Heng et al, Current Legal Issues in the Internationalization of Business Enterprises, (Butterworths, Singapura, 1996),hlm. 323. Menyatakan : “... Developing countries have the right to control and access their own genetic resources and also to obtain some fair and equitable share of the benefits aring from their commercial and other utilization ". 
Teknologi yang dimaksudkan dalam pemanfaatn sumber-sumber genetik ini adalah bioteknologi. Hubungan antara hak atas kekayaan intelektual dan alih teknologi bioteknologi merupakan suatu masalah yang komplek dan sulit. Pasal 16 Konvensi Keaneka-ragaman Hayati merupakan ketentuan yang secara ekplisit. menunjuk adanya keterkaitan antara alih teknologi dan Hak Atas Kekayaan Intelektual. Pasal 16 (3) secara langsung mengatur mengenai hubungan antara hak atas kekayaan intelektual dengan akses terhadap alih teknologi dalam pemanfaatan sumber-sumber genetik. Pasal 16 ayat (3) menyatakan:

"Each Contracting Party shall take legislative, administrative or policy measures, as appropriate, with the aim that Contracting Parties, in Particular those that are developing countries, which provide genetic resources are provided access to and transfer of technology which makes use of those genetic resources, on mutually agreed terms, including technology protected patents and other intellectual property rights, where necessary, through the provisions of Articles 20 and 21 and in accordance with international law and consistent with paragraphs 4 and 5 below." Dalam Pasal 16 ayat (3) ini menghendaki adanya usaha dari setiap negara peserta untuk mendorong sektor swasta untuk melaksanakan penelitian dan alih teknologi, mengingat sektor swasta memegang peranan yang penting dalam pengembangan bioteknologi, karena perkembangan yang sangat cepat dalam bidang bioteknologi dilakukan oleh sektor swasta. Oleh karena itu keberhasilan dalam pengembangan bioteknologi dan alih teknologi ini sangat diperlukan adanya kerja sama antara pemerintah dan pihak swasta.

Peranan yang fundamental Hak Atas Kekayaan Intektual (HAKI) ialah sebagai insentif dalam hal kreativitas dan untuk memfasilitasi alih teknologi. Peranan HAKI sebagai insentif hal ini disebabkan karena adanya pengkuan bahwa bahwa si penemu telah menghabiskan banyak waktu dan biaya dalam menciptakan suatu hasil karyanya. Kedua, peranan HAKI adalah untuk memfasilitasi adanya alih teknologi. Dalam hal bioteknologi, khususnya dalam hal pemuliaan tanaman yang berupa tanaman transgenik ada empat bentuk perlindungan terhadap hak atas kekayaan intelektual yang berkaitan dengan pengembangan dan alin teknologi, yaitu : paten, hak pemulia tanaman (plant breeders'rights), rahasia dagang dan merk.

Paten merupakan suatu bentuk perlindungan hukum yang diberikan kepada penemu, sehingga orang lain tidak dapat menggunakan hak tersebut tanpa seeijin si penemu. Paten ini merupakan jenis perlindungan yang sangat relevan dengan alih teknologi bioteknologi sebagai bagian dari akses sebagaimana yang diatur dalam pasal 15 Konvensi Keanekaragaman Hayati. Dengan demikian dalam hal akses terhadap sumber-sumber genetic termasuk juga untuk memperoleh perlindungan paten terhadap produk yang dihasilkan dari sumbersumber genetik, dalam rangka untuk mengembalikan biaya investasi, penelitian dan pengembangan.

Beberapa jenis varietas tanaman baru dipandang sebagai hasil dari penemuan bioteknologi , dimana si penyedia sumber-sumber genetik menghendaki akses terhadap teknologi tersebut. Bentuk perlindungan yang paling umum terhadap perlindungan varietas tanaman baru

${ }^{21} / \mathrm{d}, \mathrm{hlm} .88$. 
ialah Plant Breeder's Right(PBR's) ${ }^{21}$ yang secara umum memberikan hak monopoli kepada pemulia tanaman untuk tujuan komersiil.

Bentuk perlindungan lain yang relevan dengan bioteknologi ialah rahasia dagang (trade secret), hak ini memberikan perlindungan kepada pemiliknya untuk merahasikan informasi yang dimilikinya. Bioteknologi merupakan teknologi yang padat dengan pengetahuan. Oleh karena itu, akses terhadap informasi terhadap teknologi yang bersangkutan merupakan hal yang sangat penting dan berarti dalam alih teknologi.

Menurut kalimat pertama artikel 27 (3) b persetujuan TRIPs, anggota WTO dapat mengecualikan tanaman dan binatang (kecuali mikro organisme) dari paten dan terutama adalah proses biologi untuk menghasilkan tanaman atau binatang (kecuali proses non biologi dan proses mikrobiologi). ${ }^{22}$ Ketentuan ini memiliki implikasi yang sangat luas. Ketentuan ini mensyaratkan negara-negara berkembang untuk memberikan perlindungan paten terhadap mikro organisme dan terhadap proses non biologi dan non mikro-organisme, senhingyja negara-negara berkembang diwajibkan untuk memberikan perlindungan terhadap biji (benih ). Hal ini akan meningkatkan biaya dan sebagai konsekuensinya akan mempengaruhi sejumlah besar penduduk yang bergantung pada pertanian.

\section{Paten}

Paten diterapkan pada jenis teknologi mekanis, kimia, elektrik, produk biologi dan proses, dan jika diijinkan termasuk juga organisme hidup. Paten sebagaimana juga bentuk Hak Atas Kekayaan Intelektual lain, hak ini dilaksanakan untuk menseimbangkan antara penemu dan masyarakat. Masyarakat memberikan hak sebagian monopoli kepada penemu dalam jangka waktu sementara. "Sementara" merujuk kepada lamanya perlindungan yaitu 20 tahun. Sedangkan sebagian merujuk kepada luasnya perlindungan, tingkat perbedaan ini disyaratkan sebelum pengajuan paten. Kalau setelah masa perlindungan habis,maka tidak hanya akan membuka kompetisi bebas tetapi juga akan memperoleh keuntungan dengan adnya tambahan teknologi yang sebelumnya tidak ada. Walaupun paten dalam sistem hukum Kekayaan Intelektual diatur secara nasioanal, yang berbeda dari satu negara dan negara lain, namun dalam halhal persyaratan umum telah terjadi suatu kesamaan dan keseragaman. Persyaratanpersyaratan ini diterapkan dalam industri, termasuk industri bioteknologi, termasuk juga persyaratan kebaharuan, stabilitas dan keseragaman.

Inovasi dalam bioteknologi telah menimbulkan beberapa permasalahan dalam hukum paten. Ada empat macam penemuan bioteknologi yang dapat menjadi subjek hokum paten yaitu: produk, komposisi, penggunaan dan metode penggunaan. Produk adalah sesuatu yang nyata yang berupa material atau entity termasuk organisme itu sendiri, bagian dari organisme (misalnya:sel), substansi yang dihasilkan dari rekayasa genetika. Komposisinya merupakan campruran antara substansi atau organisme, dalam hal ini mungkin salah satu unsurnya sudah diketahui atau sudah ada,

${ }^{22}$ Marguilies, R.L., "Protecting Biodiversity: Recognizing Intellectual Property Rights in Plant Genetic Resources". (Michigan Journal Of International Law, 1993), hlm. 74. 
akan tetapi kombinasi dari kedua unsur ini dapat menimbulkan suatu produk baru. Pengajuan paten terhadap bioteknologi konvensional menggunakan mikro organisme atau sel yang lebih tinggi dari organisme untuk memproduksi produk baru atau untuk memproduksi produk yang sudah dikenal dengan cara baru. Salah satu problem yang berkaitan dengan penemuan bioteknologi ialah penemuan dalam bidang proses yang mungkin dapat terulang oleh ahli lain. Masalah ini ditujukan kepada pemanfaatan koleksi jaringan yang didepositkan untuk "paten jaringan".

Paten dalam bioteknologi menimbulkan permasalahan pada waktu diterapkan pada penemuan mikrobiologi. ${ }^{23}$ Hal ini disebabkan, karena suatu pengulangan tidak dapat dijamin hanya dengan menggunakan gambaran tertulis saja. Oleh karena itu banyak negara yang membentuk undang-undang untuk mengatasi masalah tersebut dengan membuat suatu peraturan khusus yang mencakup mikro organisme Salah satu Konvensi Internasional yang mengatur hal tersebut yaitu The Budapest Treaty on the International Recognition of the Deposit of Micro-organisms for the Purposes of Patent Procedure (197) ${ }^{24}$ Treaty ini secara keseluruhan berhubungan dengan mikro organisme. The Budapest Treaty menyediakan suatu sistem yang seragam tentang pendepositan atau penyimpanan mikro organisme. Budapest Treaty juga mengakui koleksi jaringan tertentu sebagai "International Depositary Authorities " (IDA's) dan juga de- posit tunggal yang dibuat oleh IDAs diterima : oleh setiap negara anggota Budapest Treaty dan persyaratannya memenuhi ketentuan nasional negara anggota tersebut.

Paten sebagai salah satu subjek dalam perjanjian lisensi memainkan peranan penting di negara-negara berkembang. Pertama melalui ekspor ke negara-negara penerima teknologi, yang kedua melalui pembangunan pabrik di negara penerima lisensi teknologi tersebut. Dalam rangka hubungannya dengan implementasi Konvensi Keanekaragaman Hayati, paten sangatlah penting untuk melindungi kekayaan intelektual dalam alih teknologi, karena negara maju sebagai pemilik paten bioteknologi menginginkan perlindungań. Di lain pihak negara berkembang yang menyediakan sumber genetik juga mempunyai hak untuk akses dan alih teknologi supaya mereka juga dapat mengusahakan sendiri. Oleh karena itu paten bioteknologi bukan hanya merupakan hak negara maju saja, tetapi seharusnnya dibagi dengan negara berkembang yang telah menyediakan sumber genetik. Paten dapat didefinisikan sebagai berikut :

"A statury privilege granted by a govemment to an inventor and to other persons deriving their rights from the inventor, for a fixed period of years, to exclude otherpersons from manufacturing, using or selling a patented product or from utilizing a patented method or proccess". ${ }^{25}$

Beberapa masalah yang timbul dari paten antara lain ketidakmampuan untuk menggunakan bahan domestik dan ilmu pengetahuan lokal

${ }^{23}$ Microbiological processes, product produced by micro-organism and micro organism are all considered patentable.

${ }^{24}$ The Budapest Treaty entered into force in 1980.

${ }^{25}$ United Nations Commission on Trade and Development, "The Role of the Patents System in the Ttransfer of Technology to Developing Countries", United Nation Document TD/B/Ac.11/19/rev.1, 1975, hlm.5. 
sehingga membatasi prospek untuk meningkatkan kemampuan keja. ${ }^{26}$ Oleh sebab itu partisipasi dari pemerintah sangat diperlukan, karena pemerintah dapat menentukan jenis paten yang sesuai dengan kebijaksanaan nasionalnya.

Persyaratan paten untuk penemuan yang berkaitan dengan Living Modified Organism (LMO) ialah ${ }^{27}$ :

\section{a. Novelty}

Suatu varietas dianggap baru apabila pada saat penerimaan permohonan paten, hasil panen dari varietas tersebut belum pernah diperdagangkan di negara dimana paten didaftarkan atau telah diperdagangkan tetapi tidak lebih dari satu tahun, atau telah diperdagangkan di luar negeri tidak lebih dari empat tahun untuk tanaman semusim dan enam tahun untuk tanaman tahunan.

\section{b. Distincness}

Suatu varietas dianggap unik apabila varietas tersebut dapat dibedakan secara jelas dengan varietas lain yang keberadaannya sudah diketahui secara umum pada saat penerimaan permohonan paten.

\section{c. Uniformity}

Suatu varietas dianggap seragam apabila sifat-sifat utama atau penting pada varietas tersebut terbukti seragam meskipun bervariasi sebagai akibat dari cara tanam dan lingkungan yang berbeda-beda.

\section{d. Stability}

Suatu varietas dianggap stabil apabila sifat-sifatnya tidak mengalami perubahan setelah ditanam berulang-ulang, atau untuk diperbanyak melalui siklus perbanyakan khusus, tidak mengalami perubahan pada setiap akhir siklus tersebut.

Ditetapkannya paten pada makluk hidup akan berdampak monopoli atas hasil-hasil pertanian oleh perusahaan-perusahaan transnasional yang bergerak dalam bidang bioteknologi. Misalnya, sebuah perusahaan yang diberikan satu paten akan menguasai seluruh hasil rekayasa genetika yang dilakukan pada gen kapas dan seluruh variasi hasil rekayasa genetika pada tanaman kapas. Hal ini akan membuat perusahaan tersebut menguasai seluruh produksi kapas dunia, sehingga akan merugikan negara-negara lain khususnya negara berkembang. ${ }^{28}$ Bahkan muncul kasus yang sangat merugikan suatu negara, misalnya, pemberian paten oleh Amerika terhadap pengobatan kuno yang mempergunakan daun-daunan, dengan paten No. $5,401,504$, yang sebenarnya telah dikenal oleh orang-orang Indian beberapa abad yang lalu. Kemudian, Amerika juga memberikan paten terhadap beberapa varietas yang sama dengan tanaman yang telah tumbuh beberapa abad yang lalu di beberapa wilayah geografis, misalnya dengan diberikannya paten No. $5,663,464$ kepada Rice - Tec Corporation atas varietas padi Basmati, yang merupakan jenis padi yang wangi yang sebenarnya telah tumbuh di di India dan Pakistan. ${ }^{29}$ 78.hlm. 57.

${ }^{26}$ UNCTC, License Agreement in Developing Countries, 1987, United Nations Document, ST/CTC/

${ }^{2}$ Pasal 5-9 International Convention for the Protection of New Varieties of Plants, 1991. Lihatjuga Rule 13 bis Invention Relating to Biological Material Patent Cooperation Treaty, 1978. ${ }^{28}$ Hira Jhamtani, Ancaman Globalisasi dàn Imperialisme Lingkungan, (INSIST Press, Yogyakarta, 2001), hlm. 5-6.

${ }^{29}$ A, Kothari, "Biodiversity and Intellectual Property Rights: Can the Two Coexist?", Linkages Joumal, Vol. 4 No.2, 28 Mei 1999. hlm.1 sebagaimana dikutip oleh Nandang Sutrisno, dalam, Erman Rajagukguk (ed), , op.cit.hlm. 103. 


\section{Plant Breeder's Rights}

Plant Breeders. Rights (PBR's) merupakan suatu sistem paten khusus seperti paten yang diterapkan pada pemulia tanaman. PBR's mula-mula disistematisasi pada tahun 1961 dalam Intemational Union for the Protection of New vanieties of Plants (UPOV). Dalam hukum paten disyaratkan adanya kebaharuan (novelty), (Non-obviousness) dan kegunaan (utility), sedangkan dalam PBR's menggunakan persyaratan distinctness, uniformity, and stability. Keseragaman dan kestabilan dipersyaratkan dalam hal reproduksi yang terjadi dalam suatu spesies dari generasi satu ke generasi yang berikutnya. Pengujian yang paling penting ialah mengenai distinctness untuk suatu varietas tanaman harus jelas-jelas berbeda dari varietas yang sudah dikenal.

PBR's dibedakan dengan paten karena adanya hak istimewa yang dimiliki oleh para petani dan adanya pengecualian penelitian, yang kadang-kadang sering disebut "breeder privilege". ${ }^{30}$ Hak petani adalah hak yang dimiliki petani untuk memiliki bibit untuk suatu alasan yang sangat penting (petani menyimpan benih untuk atau untuk Bin Competition). Pengecualian penelitian menunjuk kepada hak untuk menggunakan varietas yang dilindungi sebagai bahan asal pembentukan varietas baru atau untuk penggunaan penelitian yang lain.

Kalau diperhatikan perbedaan antara paten dan PBR's, bahwa PBR's kurang memberikan perlindungan dari pada paten. Perlindungan ini juga diterapkan pada selunuh tanaman atau bagian dari tanaman. Sedangkan apa yang tidak dilindungi ialah karakteristik yang unik dari suatu varietas. Dengan alas an tersebut, maka tidak ada perlindungan nyata yang disediakan terhadap suatu varietas yang menggunakan gen untuk dilakukannya tindakan rekayasa dimana gen tersebut secara hokum dapat dihilangkan atau digunakan dalam varietas lain atau ditambah dengan unsur-unsur lain. ${ }^{31}$

\section{Trade Secrets}

Trade Secrets dimaksudkan untuk melakukan perlindungan terhadap informasi yang dijaga kerahasiaanya yang tidak boleh disebarkan tanpa seijin si pemilik informasi, sehingga kalau hal ini dilanggar, si pelanggar akan dikenai hukuman untuk membayar harga dari informasi yang dirahasiakan tersebut. Contoh daripada trade secrets ialah termasuk praktek untuk meningkatkan effisiensi proses breeding. Tidak seperti paten dan PBRs, trade secrets ini tidak mensyaratkan adanya pendaftaran formal, tetapi syaratnya ialah bahwa informasi tersebut harus bernilai ekonomi dan ada usaha untuk tetap menjaga kerahasiaan informasi tersebut.

Selain itu dalam Pasal 16 ayat (5) menekankan pada negara peserta untuk bekerjasama dan menjamin bahwa IPR yang dilaksanakan adalah untuk mendukung tercapainya tujuan konvensi dan bukannya bertentangan dengan tujuan konvensi. Ketentuan dalam pasal ini hanya menyebutkan bahwa IPR mempengaruhi pelaksanan konvensi ini tetapi tidak menyebutkan apakah pengaruh ini pengaruh. positip atau negatif.

${ }^{30}$ Jeffrey A. McNeely and Lothar Gundling, "Guide to the Convention on Biological Diversity ", Environmental Plicy and Law Paper, No. 30, (IUCN-The World Conservation Union, 1994), him.88.

${ }^{31}$ UNEP/CBD/COP/2/17, hlm.5. 
Lebih jauh lagi, dalam Pasal 16 ayat 4 dan 5 yang didukung oleh ayat 3 , menyebutkan bahwa pelakssanaan pasal ini harus konsisten dengan hukum internasional, ini berarti termasuk sistem hukum internasional mengenai hak atas kekayaan intelektual. TRIPs menciptakan suatu standar minimum untuk perlindungan hak atas kekayaan intelektual, tetapi juga menekankan kepada semua negara peserta untuk memenuhi persyaratan minimum yang telah ditetapkan di dalam TRIP's. Selain itu TRIP's juga mensyaratkan kepada semua negara penanda tangan, termasuk 70 negara berkembang untuk melakukan perlindungan terhadap hal-hal sebagaimana yang disebutkan dibawah ini dalam jangka waktu 5-10 tahun tergantung dari perkembangan masing-masing negara.

\section{Simpulan}

TRIP's sebagai suatu regim hukum yang berkaitan dengan perdagangan dan perlindungan hak atas kekayaan intellektual memilikiki dampak positif dan negatif terhadap Konvensi Keanekaragaman Hayati. Diterapkannya TRIP's dalam Konvensi Keanekaragaman Hayati, memberikan perlindungan hukum kepada para inventor di bidang biotehnologi yang diatur dalam Konvensi Keanekaragaman Hayati, sehingga mendorong orang untuk melakukan penemuan- penemuan baru di bidang bioteknolgi, misalnya penemuan varietas tanaman dengan rekayasa genetika akan menambah keanekaragaman hayati, kalau itu dilakukan berdasarkan ketentuan-ketentuan mengenai keselamatan hayati sebagaimana yang diatur dalam Konvensi Keanekaragaman Hayati.

Di lain pihak, penerapan TRIP's dalam Konvensi Keanekaragaman Hayati, memberikan peluang-peluang bagi negara-negara maju melakukan pematenan terhadap pengetahuan tradisional yang sudah turun-temurun dimiliki oleh masyarakat tradisional suatu negara. Bahkan pematenan terhadap suatu jenis tanaman tertentu yang ada secara alami. Di samping itu dengan adanya periindung hak atas kekayaan intelektual terhadap suatu jenis tanaman hasil rekayasa genetika yang dihasilkan oleh bioteknologi akan menyebabkan berkurangnya keanekaragaman hayati, karena tanaman hasil rekayasa agar mengandung bahan-bahan beracun yang bersifat obat atau pestisida akan membawa resiko bagi makluk hidup lain.

\section{Daftar Pustaka}

Abercrombie M., M. Hickman (et,al), Dictionary of Biology, Penguin, England, 1980

Erman Rajagukguk (ed ), 75 Tahun Prof. Dr. Koesnadi Hardjasoemantri, SH.,ML, Program Pascasarjana Universitas Indonesia, Jakarta, 2001.

Fidler David P., International Law and Public Health : Materials on and Analysis of Global Health Jurisprudence, Transnational Publishers, Inc, New York, 2000.

Lin Heng Lye, Current Legal Issues in the Internationalization of Bussiness Enterprises, Butterworths, Singapore, 1996.

Mc Neely Jeffrey A. and Lothar Gundling, " Guide to the Convention on Biological Diversity ", Environmental Policy and Law Paper No. 30, IUCN -The World Conservation Union, 1994.

Mannion .A.M. dan S.R. Bowlby (ed), Environmental lssues in the 1990s, John Wiley \& Sons Ltd, , 1992.

Marguilies R.L, "Protecting Biodiversity: Recognizing Intellectual Property 
Rights in Plant Genetic Resources". Michigan Journal Of International Law, 1993.

Otto Soemarwoto, Ekologi Lingkungan Hidup dan Pembangunan, Djambatan, 1991

Sugiono Moeljoprawiro, Prospek Bioteknologi Dalam Pembangunan Pertanian, Kantor Menteri Negara lingkungan Hidup, Jakarta, 1994, hlm.37. "

Sands Phillippe, Principles of International Environmental Law I Frameworks Standards and Implementation, Manchester University Press, Manchester, 1995.

International Convention for the Protection of New Varieties of Plants, 1991.

Konvensi Keanekaragaman Hayati Tahun 1992.

Kantor Menteri Negara Lingkungan Hidup dan United Nations Development Programme, Agenda 21 Indonesia : Strategi Nasional Untuk Pembangunan Berkelanjutan,
Menteri Negara Lingkungan Hidup, Jakarta, 1997, hlm. 539.

Patent Cooperation Treaty, 1978.

Preparatory Committee for UNCED " Report on the Transfer of Technology : Report by the Secretary General of the Conference ", AlConf/51/AC/53, United Nations, New York, hlm.3

The Budapest Treaty .

United Nations Commission on Trade and Development, "The Role of the Patents System in the Ttransfer of Technology to Developing Countries", United Nation Document TD/B/Ac.11/19/rev.1. 1975, hlm. 5.

UNCTC, License Agreement in Developing Countries, 1987, United Nations Document, ST/ CTC/78.hlm. 57.

UNEP/CBD/COP/2/17, hlm.5.

WTO Secretariat ( ed ), Trade, Development and the Environment, Kluwer Law International, London, 2000, hlm. 72. 